\title{
スパッタリング法で作製した $\mathrm{SrTiO}_{3}$ 薄膜の 結晶性と誘電特性*
}

\author{
田中 伸治**. 山田 一**.中川原 修** \\ 小林 真人** . 田中 克彦 ${ }^{* *} \cdot$ 片山 祐三**
}

（受理1997年 1 月 6 日，掲載決定1997年 2 月 1 日）

Crystallinity and Dielectric Properties of $\mathrm{SrTiO}_{3}$ Films Prepared by Sputtering

Shinji TANAKA, Hajime YAMADA, Osamu NAKAGAWARA, Masato KOBAYASHI, Katsuhiko TANAKA and Yuzo KATAYAMA

(Murata Manufacturing Co., Ltd. 2-26-10 Tenjin, Nagaokakyo, Kyoto)

(Received January 6, 1997, Accepted February 1, 1997)

\section{1. はじめに}

$\mathrm{SrTiO}_{3}$ は強誘電性がなく, 比誘電率がバルク值で300 程度と比較的高いため, 近年 $\mathrm{SiO}_{2}, \mathrm{SiNx}$ 等に代わる高 周波用デバイスの高誘電率薄膜材料として有望視されて いる1).

$\mathrm{SrTiO}_{3}$ 薄膜を回路素子として応用する場合，素子の 作製プロセス上，成膜温度が低い方が好ましい，このた め成膜温度をできるだけ下げ良好な特性を得ることに関 心が寄せられている. $\mathrm{SrTiO}_{3}$ 薄膜の場合, $\mathrm{SiO}_{2}, \mathrm{SiNx}$ 等の非晶質の誘電体薄膜とは異なり, 誘電特性の成膜温 度依存性や膜厚依存性が顕著に現れてくる2).これらの 依存性を把握しておくことがペロブスカイト型結晶構造 を有する誘電体薄膜の作製に括いて重要である.

本報告では成膜温度 $280^{\circ} \mathrm{C}$ の低温で作製した薄膜の結 晶性と誘電特性の膜厚依存性を評価し，成膜初期層の影 響について明らかにする。

\section{2. 実験および評価方法}

成膜方法には RF マグネトロンスパッタリング法を採 用し，ターゲットとして $\mathrm{SrTiO}_{3}$ 焼結体を用いた。ガス

\footnotetext{
* 1996年10月30日 第37回真空に関する連合講演会に於いて発表

** (侏)村田製作所技術開発本部（宁520-23 滋賀県野洲郡野洲町大字大䈷 原2288)
}

種にはアルゴンと酸素の混合ガスを使った．基板には $\mathrm{Pt} / \mathrm{Ti} /$ ガラスを用いた. $\mathrm{SrTiO}_{3}$ 薄膜の膜厚は成膜時間 で制御し，段差計を用いて測定した．本実験では成膜温 度 $280^{\circ} \mathrm{C}$ と固定し, 膜厚を $35 \sim 350 \mathrm{~nm}$ の範囲で変えた試 料を作製した.

結晶性の評価には XRD (薄膜法)と TEMを用いた. また誘電特性は $\mathrm{Pt}$ を下部電極とし, $\mathrm{SrTiO}_{3}$ 薄膜上に電 極のパターニングをすることで形成された MIM キャパ シタを用いて，インピーダンスアナライザにて $1 \mathrm{MHz}$ で評価した。

\section{3. 実 験 結 果}

Fig. 1 に35〜350 nm の膜厚で作製した $\mathrm{SrTiO}_{3}$ 薄膜 のXRDの测定結果を示す．いづれの膜厚に扎いても (110)等のピークが現れて拉り，多結晶であることがわ かる、最も大きいピークである(110)に注目すると, 膜 厚が $35 \mathrm{~nm}$ から $70 \mathrm{~nm}$ へ厚くなると半值幅が減少し結晶 性の向上がみられる。また若干ではあるが，70 $\mathrm{nm}$ より 厚くなるとピークが鈍ってくる傾向がある.

Fig. 2 に $\mathrm{SrTiO}_{3} / \mathrm{Pt}$ 電極界面の断面 TEM 写真を示 す.この図から成膜の初期ではアモルファス相になって いることがわかる.アモルファス相の厚さは10〜 $50 \mathrm{~nm}$ とばらついており, 平均して $30 \mathrm{~nm}$ 程度である.

Fig. 3 K $\mathrm{SrTiO}_{3}$ 薄膜の膜厚と比誘電率との関係を示 す. 膜が薄くなると比誘電率が急激に減少する. Fig. 3 


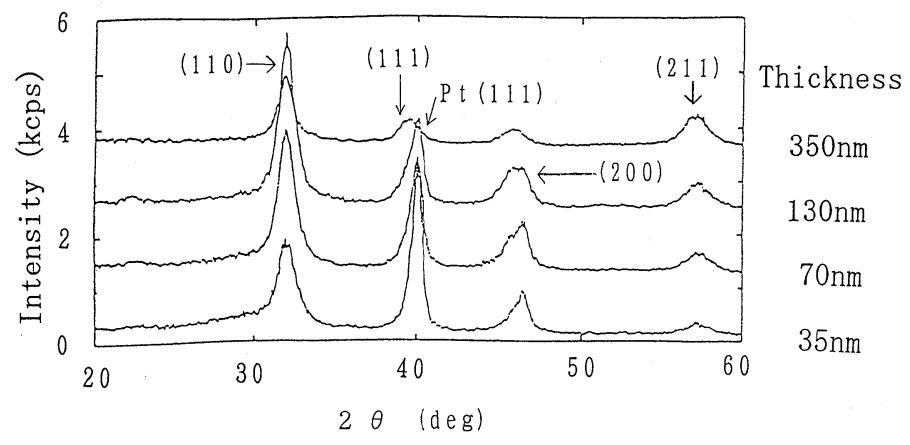

Fig. 1 XRD patterns of $\mathrm{SrTiO}_{3}$ films on $\mathrm{Pt} / \mathrm{Ti} /$ glass substrates.

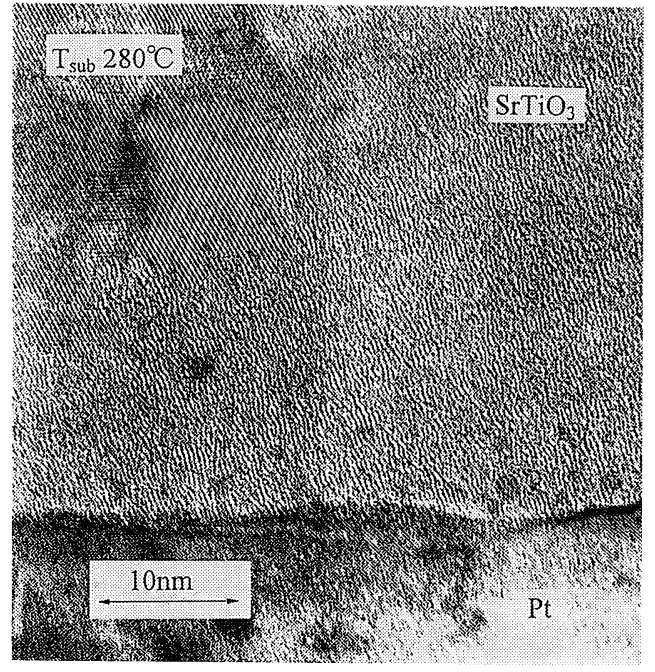

Fig. 2 Cross-sectional TEM image of a $\mathrm{SrTiO}_{3}$ film on $\mathrm{Pt}$.

のデータを基にカーブのフィッティングを行い, 膜厚 $50 \mathrm{~nm}$ ごとに層分離して膜厚方向の各区間に㧧ける比誘 電率を求めるとFig. 4のようになる.膜厚の区間は計 算上任意にできるが，実測值を考慮し $50 \mathrm{~nm}$ 間隔とし た. 膜厚 $0 \mathrm{~nm}$ は $\mathrm{SrTiO}_{3} / \mathrm{Pt}$ 電極界面である. Fig. 4 か ら 0 50 nm では比誘電率が39と低く，成膜初期層は低 誘電率であることがわかる．実際の低誘電率層の厚さは

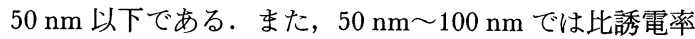
が173 と急激に増加する. $100 \mathrm{~nm}$ 以上になると比誘電率 は緩やかに減少している。

\section{4. 考察}

Fig. 3 に示す比誘電率の膜厚依存性の主要因は, Fig.

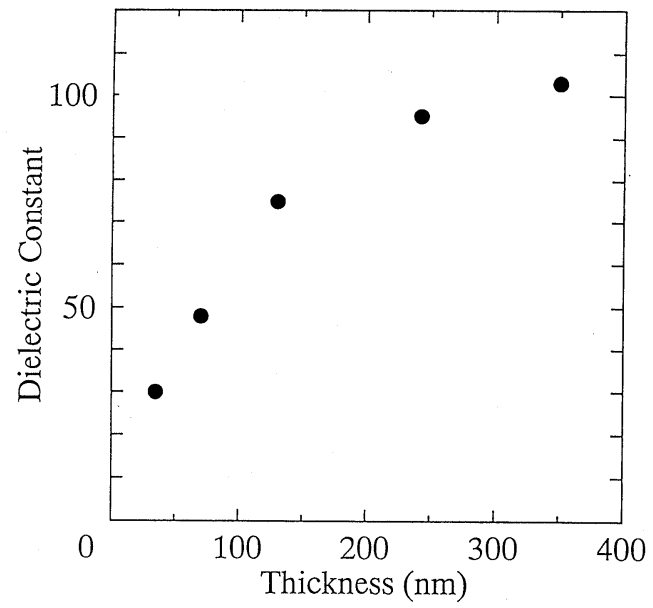

Fig. 3 Dielectric constant dependence on thin-film thickness.

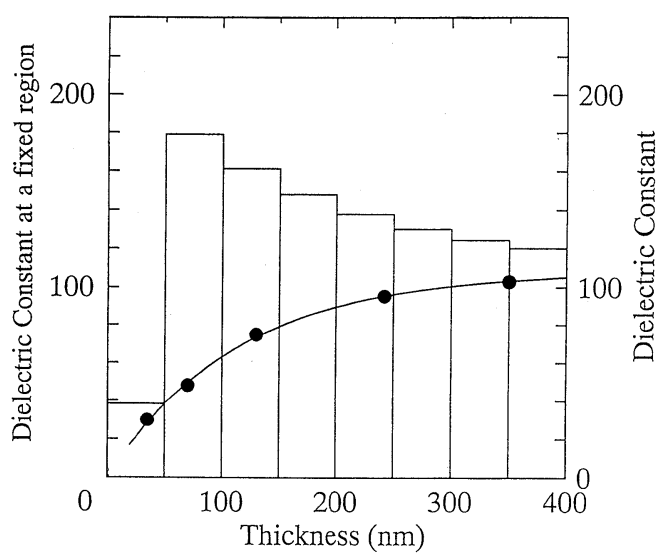

Fig. 4 Dielectric constant dependence on a fixed region in the direction of the thickness. A fixed region is $50 \mathrm{~nm}$ thick. 
4からわかるよ5に成膜初期層が低誘電率になっている ためである．この低誘電率層があるために比誘電率は膜 厚 $300 \mathrm{~nm}$ ぐらいまでは大きな変化を示し， ～ $300 \mathrm{~nm}$ 以 上では比較的低い值で飽和しはじめてしまう．成膜初期 層での誘電率を上げることが膜全体の誘電率を上げるの に重要である.

成膜初期層の結晶構造はアモルファスであり，低誘電 率層に対応していると考えられる。アモルファスである ためにペロブスカイト構造に起因する分極を発生させる ことができず誘電率が低くなっている．XRDの結果か らも同様のことが推測される.すなわち, 膜厚 $35 \mathrm{~nm}$ は大半がアモルファス相であるが, 若干の結晶相が含ま れている.このため XRD ではブロードなピークを示し ている. 膜厚 $70 \mathrm{~nm}$ では結晶相の領域が増えるのでピー クは鋭くなり, 誘電率も上がる.

\section{5. ま と}

成膜温度が $280^{\circ} \mathrm{C}$ と比較的低い場合, $\mathrm{SrTiO}_{3}$ 薄膜の成 長初期にはアモルファス相が形成され，膜厚が执よそ $30 \mathrm{~nm}$ 以上で結晶化がはじまる. 膜厚方向の比誘電率は 下部電極より $50 \mathrm{~nm}$ 程度のところで急激に変化してい る. 高い誘電率を持つ $\mathrm{SrTiO}_{3}$ 薄膜を作製するには, 成 膜初期層の結晶性の向上が重要である.

\section{〔文献〕}

1) K. Ikuta, Y. Umeda and Y. Ishii: Int. Conf. Solid State Devices and Materials, (1995) 509.

2) 中川原修, 田中伸治, 出口洋一, 斎藤 彰, 小林真 人, 田中克彦, 片山祐三 : 1996年秋期応用物理学会 $7 \mathrm{a}-\mathrm{F}-2$. 